\title{
Witold Adamczewski
}

\section{Uznanie skutków cywilnych małżeństwa kanonicznego $\mathrm{w}$ najnowszych umowach konkordatowych}

Ius Matrimoniale 1 (67), 169-193

1996

Artykuł został zdigitalizowany i opracowany do udostępnienia w internecie przez Muzeum Historii Polski w ramach prac podejmowanych na rzecz zapewnienia otwartego, powszechnego i trwałego dostępu do polskiego dorobku naukowego i kulturalnego. Artykuł jest umieszczony w kolekcji cyfrowej bazhum.muzhp.pl, gromadzącej zawartość polskich czasopism humanistycznych i społecznych.

Tekst jest udostępniony do wykorzystania w ramach dozwolonego użytku. 


\section{Witold Adamczewski SJ}

\section{Uznanie skutków cywilnych małżeństwa kanonicznego w najnowszych umowach konkordatowych}

Kościół był zawsze świadomy swojej kompetencji rozciągającej się nad instytucja małżeństwa. $Z$ czasem wypracował swój własny - bazujący na nauce o sakramentalności małżeństwa' - system prawa małżeńskiego, który opierając się na prawie Bożym, tak naturalnym, jak i pozytywnym, zawierał również elementy prawa czysto kościelnego. Kontrowersje wokół kompetencji Kościoła nad małżeństwem chrześcijan pojawiły się zasadniczo w XVI w. ${ }^{2} \mathrm{i}$ w sposób oczywisty związane były z reformacją $\mathrm{i}$ kwestionowaniem sakramentalności małżeństwa. Nie wchodząc w bardziej szczegółowe rozważania natury historycznej, można przyjać, że przy okazji obrony swojej kompetencji nad małżeństwem, wypracowana została przez Kościół formula, zawarta najpierw w kodeksie prawa kanonicznego $\mathrm{z}$ $1917 \mathrm{r}^{3}$, a następnie przejęta $-\mathrm{z}$ pewną modyfikacją ${ }^{4}$ - do obu aktualnie

' Chociaż dogmat o sakramentalności małżeństwa został ogłoszony na soborze trydenckim (sesja 24, 11 listopada 1563 r., can.1 de sacramento matrimonii: Conciliorum Oecumenicorum Decreta, Friburgi Br. 1962, s. 730; już jednak na sesji 7 w dniu 3 marca 1547 r. małżeństwo zostało wyliczone wśród siedmiu sakramentów w can.l de sacramentis in genere: tamże, s.660), to jednak już od początków Kościoła istniala świadomość, że małżeństwo zostało przez Chrystusa obdarzone szczególną świętością (zob. U. N a v a r r e t e, De vinculo matrimonii in theologia et iure canonico, w: Vinculum matrimoniale, Roma 1973, s. 105). W XII w., kiedy krystalizowało się pojęcie sakramentów, małżeństwo było zaliczane do ich liczby. W dokumentach Magisterium po raz pierwszy małżeństwo jako sakrament zostało określone na synodzie w Weronie w 1184 r. (zob. Enchiridion symbolorum, definitionum et declarationum de rebus fidei et morum, Barcinone-Friburgi Br--Romae 1976, s. 242).

${ }^{2}$ Właściwie aż do XI w. w społeczeństwie jednoznacznie chrześcijańskim nie było miejsca na konflikty w sprawie kompetencji nad małżeństwem. Jeśli pojawiały się jakieś kontrowersje, to raczej miały one charakter teologiczny i nie wkraczały w sferę zycia społecznego. Zob. L. Ch i a p p e t a, Il matrimonio nella mova legislazione concordataria, Roma 1990, s. 44; R.Minnerath, L'Église et les états concordataires (1846-1981). Le souveraineté spirituelle, Paris 1983, s. 333.

${ }^{3}$ Zob. kan. 1016. Oczywiście już wcześniej można znaleźć zaczątki tego sformułowania. Za najstarsze bezpośrednie źródło tego przepisu można uznać konstytucję apostolską Auctorem fidei Piusa VI z dnia 28 sierpnia 1794 r. Zob. P. G a s p a r r i, Codicis Iuris Canonici Fontes, tom. 2, Vaticani 1948, s. 703.

`Kodeks prawa kanonicznego z 1917 r. mówiąc o kompetencji Kościoła odnosi się do 
obowiązujących kodeksów', w których można znaleźć stwierdzenie, iż matżeństwo katolików, chociażby tylko jedna strona była katolicka, podlega nie tylko prawu Bożemu, lecz również kanonicznemu, z zachowaniem kompetencji władzy państwowej odnośnie czysto cywilnych skutków tegoż malżenstwa.

Kształtowanie się doktryny o kompetencjach państwa względem czysto cywilnych skutków małżeństwa dokonywało się więc przede wszystkim w kontekście obrony słusznych praw Kościoła, ale jednocześnie związane było z tą konsekwencją dziejową wobec której stanął Kościół, jaką było wprowadzenie instytucji małżeństwa cywilnego. ${ }^{2}$ Fakt tworzenia się nowoczesnych państw i związana $\mathrm{z}$ tym ich aktywność legislacyjna porządkująca życie indywidualne i zbiorowe w ramach tej społeczności, siła rzeczy postawiły na nowo problem koordynacji wzajemnych relacji państwo-kościół w różnorakich dziedzinach, w tym również - a może przede wszystkim - w sprawach dotyczących małżeństwa. ${ }^{3}$ Pomijając szczególową analizę stanowiska Kościoła wobec praw ustanawianych przez państwo w materii małżeńskiej ${ }^{4}$, wystarczy powiedzieć, że konfrontacja obu tych rzeczywistości - duchowej i doczesnej - doprowadzila do powstania teorii społeczności doskonałej, której zaczątki można znaleźć w XVII w. w Würzburgu, a pełne rozwinięcie w XIX w. w ramach tzw. szkoły rzymskiej i jej systemu publicznego prawa kościelnego. ${ }^{5}$

Faktem więc stało się pojawienie dwóch systemów prawa małżeńskiego, które z różnych - często konkurencyjnych - punktów widzenia regulowały sprawy dotyczące tej podstawowej instytucji ludzkiej. Obecnie można

„małżeństwa ochrzczonych", podczas gdy w kodeksach późniejszych mówi się już o „małżeństwie katolików".

' Zob. kan.1059 KPK oraz kan.780 \$ 1 KKKW.

${ }^{2}$ Po raz pierwszy wprowadzono je w 1580 r. w Holandii z zachowaniem jednak zasady dobrowolności. Natomiast obligatoryjne potraktowanie małżeństwa jako instytucji pozostającej w ekskluzywnej kompetencji państwa można znaleźć w Konstytucji francuskiej z dnia 14 września $1791 \mathrm{r}$., w której stwierdza się, że tylko te małżeństwa będą uznane przez państwo, które zostały zawarte $w$ formie świeckiej. Zob. L. C h i a p p e t t a, dz. cyt., s. 44-45; R. Minnerat h, dz. cyt., s. 337.

${ }^{3}$ Zob. R. M in ner at h, dz. cyt., s. 331 .

${ }^{4}$ Więcej na ten temat można znaleźć w: F.M. C a p p e 11 o, Tractatus canonico-moralis de sacramentis, tom V: de matrimonio, Torino 1961, s. 658-661.

s Szczegóły tej teorii można znaleźć w: A. O $\mathrm{t} t \mathrm{a} \vee \mathrm{i}$ a $\mathrm{n} \mathrm{i}$, Institutiones iuris publici ecclesiastici, tom.1, Vaticani 1958, s. 29-56. 
mówił o trzech systemach państwowych regulujących formę zawierania małżeństwa. Pierwszym $\mathrm{z}$ nich jest system obligatoryjnego małżeństwa cywilnego.' Drugim systemem jest system fakultatywny, dopuszczający zawarcie małżeństwa bądź w formie cywilnej, bądź w formie religijnej. System ten stosuje wiele państw, i to nie tylko tych, które podpisały konkordaty ze Stolicą Apostolską. Najlepszym przykładem mogą być Stany Zjednoczone Ameryki. Dla pełnego obrazu należy jeszcze dodać trzeci system, a mianowicie obligatoryjne zawieranie małzeństwa $w$ formie religijnej, z tym że $w$ dzisiejszych czasach występuje on wyłącznie w tradycyjnych państwach wyznaniowych i jest niejako naturalną konsekwencją tego faktu ustrojowego. ${ }^{2}$

Zgodnie $z$ wyżej wspomnianą charakterystyka, uznawanie przez państwo skutków cywilnych małżeństwa religijnego na podstawie umowy konkordatowej, należy obecnie zaliczyć do systemu fakultatywnego ${ }^{3}$. Kwestie uznawania skutków cywilnych małżeństwa kanonicznego zaczęły się pojawiać w konkordatach dopiero pod koniec XIX w. Pierwszymi tego rodzaju konkordatami były umowy z Czarnogóra ${ }^{4}$ (1886) i Kolumbia ${ }^{5}$ (1887). ${ }^{6}$ Zaowocowało to później całą serią konkordatów XX w., w których

' Obowiązuje on $w$ licznych krajach, $z$ których oprócz Francji, moźna wymienić również Belgię, Holandię i in. Najczęściej, nie zabraniając zawierania małżeństwa w formie religijnej, nakłada się obowiązek zachowania precedencji formy cywilnej przed formą religijna. Zob. L. Ch i a p p e t t a, dz.cyt., s. 47; J. P r a d e r, Il matrimonio nel mondo, Padova 1986, s. 3-9.

? Głównie są to państwa muzułmańskie. Zob. L. C h i a p p e t t a, dz.cyt., s.47. Więcej na ten temat można znaleźć w: J. P r a d e r, dz. cyt., s. 15-27. Dla uzupełnienia należałoby jeszeze wspomnieć o systemie zastępczego małżeństwa cywilnego, w którym tę formę stosuje się przy braku możliwości zawarcia malżeństwa w formie religijnej. Zob. F.M. C a p p e 11 o, dz. cyt., s. 659 ; L. Ch i a p pet t a, dz. cyt., s. 48.

'Dla ścisłości należy zaznaczyć, że w ramach tego systemu tradycyjnie wyróżnia się dwie odmiany, a mianowicie system anglosaski polegający na tym, że fakultatywność dotyczy jedynie wyboru formy zawarcia małzeństwa oraz system konkordatowy, który uznaje małżeństwo katolickie jako takie z wszystkimi jego istotnymi przymiotami i elementami. Zob. J. Pra d e r, dz. cyt., s. 9-10. Podobnie również: R. N a v a r ro V a IIs, Los efectos civiles del matrimonio canónico en el Acuerdo sobre asuntos juridicos de 1979 entre la Santa Sede y el Estado espagñol, Ius Canonicum 29, 1979, n.1, s. 118-119. Problem wydaje się nieco bardziej złożony i przyjdzie jeszcze do niego wrócić.

+Zob. A. M e r c a ti, Raccolta di concordati, tom 1, Città del Vaticano 1957, s. 1048-1050.

s Zob.t a m że, tom 1, s. 1051-1061.

'Zob. R. M i n n e r a th, dz. cyt., s. 346. Wcześniejsze konkordaty, szczególnie za pontyfikatu Piusa IX (1846-1878), nie czyniły żadnej wzmianki na temat małżeństwa. Autor thumaczy to m.in. tym, że aż do połowy XIX w. Kościół zachowywał w państwach swoje 
sprawy małżeńskie stały się już nieomal klasyczną „materią konkordatową".

Z posoborowych konkordatów' sprawy uznania skutków cywilnych małżeństwa kanonicznego normowane są w umowach z Kolumbią ${ }^{2}$ (1973), Portugalią̧ (1975), Hiszpanią (1979), Włochami ${ }^{3}$ (1984) i Polską ${ }^{6}$ (1993). Również $w$ umowie konkordatowej $\mathrm{z}$ Maltą umieszczono przepisy dotyczące skutków cywilnych małżeństwa kanonicznego, lecz jej proces legislacyjny nie został jeszcze ukończony.

\section{Zasada uznania skutków cywilnych małżeństwa kanonicznego}

Na samym początku należy podkreślić, że wszystkie zapisy prawne wspomnianych wyżej konkordatów, zawierające ogólne stwierdzenia o

tradycyjne miejsce tak dalece, że - zdaniem antora - prawie ignorował fakt istnienia małżeństwa cywilnego, rozwodów, a w pewnych wypadkach nawet państwa (t a in ż e, s. 343).

'Należy się pewne wyjaśnienie terminologiczne: umowy międzynarodowe zawierane przez Stolicę Apostolską z poszczególnymi państwami noszą różne nazwy własne, wszystkie jednak należą do kategorii umów konkordatowych, czyli konkordatów (międzynarodowych umów dwustronnych, których jedną ze stron jest Stolica Apostolska). Niektóre z nich jako swoją nazwę własną noszą określenie „konkordat”.

2 Concordato fra la Santa Sede e la Repubblica di Colombia, AAS 67, 1975, n.7, s.421-434. Umowa została podpisana $w$ dniu 12 lipca $1973 \mathrm{r}$. i weszła w życie $z$ dniem 2 lipca $1975 \mathrm{r}$. Polskie tłumaczenie można znaleźć w: J.Krukowski, Konkordaty wspótczesne. Doktryna $i$ teksty, Warszawa 1995, s. 333-340.

${ }^{3}$ Protocollo addizionale al Concordato fra la Santa Sede e la Repubblica Portogese del 7 maggio 1940, AAS 67, 1975, n.7, s.435-436. Umowa została podpisana w dniu 15 lutego 1975 r. i weszła w życie $z$ dniem 23 kwietnia 1975 r. Tłumaczenie polskie w: j.w., s.386. Zgodnie z art.2 tej umowy zostały utrzymane w mocy przepisy konkordatu z 1940 r. (AAS 32, 1940, n.7, s. 217-233), stąd też zasadne wydaje się być zaliczenie go - mimo wszystko - do umów posoborowych.

+ Accordo tra la Santa Sede e lo Stato Spagñolo circa questioni giuridici, AAS 72, 1980, n. 1 , s. 29-36. Umowa została podpisana 3 stycznia 1979 r. i weszła w życie z dniem 4 grudnia 1979 r. Tłumaczenie polskie w: j.w., s.306-309.

5 Accordo tra la Santa Sede e la Repubblica italiana che apporta modificazioni al Concordato lateranense (con Protocollo addizionale), AAS 77, 1985, n.6, s.521-535. Umowa została podpisana w dniu 10 lutego $1984 \mathrm{r}$. i weszła w życie $z$ dniem 3 czerwca $1985 \mathrm{r}$. Thumaczenie polskie w: j.w., s. 423-430.

"Konkordat między Stolicq Apostolskq i Rzeczapospolita Polskq, Archiwum Nuncjatury Apostolskiej w Polsce, N.2000/93, Reg.Vl-2. Umowa została podpisana w dniu 28 lipca 1993 r. i dotychczas nie została ratyfikowana. 
uznaniu skutków cywilnych małżeństwa kanonicznego są do siebie bardzo podobne. Różnice pojawiają się dopiero w tej części przepisów, które normują procedurę wpisu zawartego małżeństwa do rejestrów państwowych lub formułuja dodatkowe warunki wymagane do jego uznania.

Ogólne formuły uznania skutków cywilnych użyte w konkordatach posoborowych są następujące:!

\begin{tabular}{|c|c|}
\hline konkordat & formula \\
\hline $\begin{array}{l}\text { KOLUMBIA } \\
\text { (art.?) }\end{array}$ & $\begin{array}{l}\text { A: lo Stato riconosce } \\
\text { B: pieni effetti civili } \\
\text { C: al matrimonio celebrato conformente } \\
\text { alle norme del diritto canonico }(\ldots)\end{array}$ \\
\hline $\begin{array}{l}\text { PORTUGALIA } \\
\text { (art.22/1940) } \\
\text { utrzymany w mocy przez } \\
\text { art.2 protokołu z } 1975 \\
\end{array}$ & $\begin{array}{l}\text { A: lo Stato portoghese riconosce } \\
\text { B: gli effetti civili } \\
\text { C: ai matrimoni celebrati in conformità } \\
\text { con le leggi canoniche }(\ldots)\end{array}$ \\
\hline $\begin{array}{c}\text { HISZPANIA } \\
\text { (art.6 ust.1) }\end{array}$ & $\begin{array}{l}\text { A: lo Stato riconosce } \\
\text { B: gli effetti civili } \\
\text { C: al matrimonio celebrato secondo } \\
\text { le norme del diritto canonico (...) }\end{array}$ \\
\hline $\begin{array}{l}\text { WLOCHY } \\
\text { (art.8 ust.1) }\end{array}$ & $\begin{array}{l}\text { A: Sono riconosciuti } \\
\text { B: gli effetti civili } \\
\text { C: ai matrimoni contratti secondo } \\
\text { le norme del diritto canonico }(\ldots)\end{array}$ \\
\hline $\begin{array}{l}\text { POLSKA } \\
\text { (art.10 ust.1) }\end{array}$ & $\begin{array}{l}\text { C: }(\ldots) \text { il matrimonio canonico } \\
\text { A: comporta } \\
\text { B: gli effetti del matrimonio contratto } \\
\text { secondo la legge polacca (...) }\end{array}$ \\
\hline
\end{tabular}

' $W$ tabeli zamieszczono formuły w autentycznej wersji włoskiej. Poniżej zaś przytoczono ich tłumaczenie polskie (w przypadku konkordatu polskiego wersja polska jest autentyczna):

Kolumbia: $\quad$ Państwo uznaje pelne skutki cywilne matzeństwa zawartego zgodnie $z$ normami prawa kanonicznego (...)

Portugalia: $\quad$ Państwo portugalskie uznaje skutki cywilne malżeństw zawartych zgodnie z przepisami prawa kanonicznego (...)

Hiszpania: $\quad$ Państwo uznaje skutki cywilne malżeństwa zawartego wedlug norm prawa kanonicznego (...)

Włochy: Uznaje sie skutki cywilne malienstw zawartych wedlug norm prawa kanonicznego (..)

Polska: (...) malzénstwo kanoniczne wywiera takie skutki, jakie pociaga za soba zawarcie matżenstwa zgodnie z prawem polskim (...). 
Już nawet pobieżna analiza tych zapisów prawnych wskazuje, że składają się one $\mathrm{z}$ trzech zasadniczych elementów, które - $\mathrm{w}$ pewnym uproszczeniu - precyzują odpowiednio:

A: zobowiązanie i jego podmiot (państwo),

B: atrybut zobowiazania (skutki cywilne),

C: przedmiot, do którego zobowiązanie się odnosi (małżeństwo kanoniczne).

We wszystkich formułach konkordatowych nie tylko, że zawarte są te same elementy, ale również występują one w tej samej kolejności.' Wyjątkiem jest tylko konkordat polski, w którym nastapiła konwersja elementów, tak że najpierw określa się przedmiot objęty zobowiązaniem (małżeństwo kanoniczne), później samo zobowiązanie bez wyraźnego odnoszenia się do państwa (wywiera), a na końcu atrybut zobowiazania (skutki cywilne).

Pamiętajac, że każdy konkordat jest dwustronną umowa międzynarodowa, nie można analizy jego zapisów ograniczać do jednego tylko punktu widzenia. Doktryna katolicka jest koniecznym punktem. odniesienia przy podejmowaniu decyzji o podpisaniu danego konkordatu i - tym samym - zobowiazaniu sie do przestrzegania jego postanowień, ale interpretacja jego zapisów musi uwzględniać dwustronny charakter umowy. Nowy element tej interpretacji będzie więc dotyczył wzajemnych relacji obu systemów prawnych, czyli prawa kanonicznego i prawa państwowego. W literaturze problem ten pojawia się w postaci pytania, na ile małżeńskie prawo kanoniczne wkracza poprzez umowę konkordatową w system prawa państwowego. ${ }^{2}$ Teoria recepcji kanonicznego prawa małżeńskiego do systemu prawa państwowego dzieli swoich zwolenników na dwie zasadnicze grupy. Część autorów opowiada się za opcją o recepcji materialnej, która zakłada, że prawo kanoniczne w zakresie wyznaczonym konkordatem staje się prawem państwowym. Większość jednak mówi jedynie o recepcji formalnej, w myśl której tylko wybrane normy prawa kanonicznego są usankcjonowane w systemie prawa państwowego, lecz nie

' Zob. J.G.M. C a r $\vee$ a j a I, El matrimonio religioso y effectos civiles en los concordatos actuales, w: Problemos entre Iglesia y Estado. Vías de solución en Derecho Comparado, Madrid 1978, s. 248.

${ }^{2}$ Takie jednostronne potraktowanie zagadnienia relacji obu systemów prawnych $\mathrm{w}$ materii małżeńskiej jest usprawiedliwione faktem, że chodzi o uznanie skutków cywilnych małżeństwa kanonicznego, a nie odwrotnie. 
stają się tym samym normami prawa cywilnego.' Wiąże się to ze stanowiskiem niektórych autorów kwestionujących tezę, zgodnie z którą uznanie skutków małżeństwa kanonicznego jest tylko uznaniem tej specyficznej formy zawierania małżeństwa za wystarczająca do nadania powstałemu zwiąkowi skuteczności w systemie prawnym danego państwa. Tak można - ich zdaniem - traktować uznanie skutków cywilnych małżeństw w przypadku wyznawców tych religii, które nie uznaja sakramentalności małżeństwa, podczas gdy w przypadku małżeństwa konkordatowego państwo zobowiązywać by się miało do uznania małżeństwa kanonicznego jako takiego, a więc $z$ wszystkim co w sposób istotny do tego związku kobiety i mężczyzny należy. Nie jest to zresztą jedynie opinia autorów, gdyż w podobnym tonie utrzymana byla nota Stolicy Apostolskiej wystosowana do Rządu włoskiego z dnia 13 czerwca 1970 r., a więc w okresie gdy prowadzone były prace mające na celu nowelizację konkordatu z $1929 \mathrm{r}^{2}$

Niewątpliwie takie traktowanie instytucji małzeństwa konkordatowego znajdowało swoje uzasadnienie w zapisach starszych konkordatów, jak chociażby w konkordacie włoskim z 1929 r. Art.34 tego konkordatu postanawiał, że ,Państwo wloskie, pragnac przywrócić instytucji matzeństwa, które jest podstawa rodziny, godność odpowiadajqca katolickiej tradycji swojego narodu, uznaje skutki cywilne sakramentalnego matżenstwa, które podlega normom prawa kanonicznego"3. Pierwszy projekt (1969) nowego konkordatu przygotowany przez wloską komisję rządową - zreszta z punktu widzenia techniki prawnej niezwykle zawiły i dalece rozmyty starał się opisać instytucję małżeństwa w kategoriach praw człowieka. Natomiast wszystkie następne projekty zawierały już formułę, która znalazła się w wersji ostatecznej włoskiego konkordatu z $1984 \mathrm{r}^{4}{ }^{4}$ Jest to

' Można tu przez analogię odwołać się do dwóch modeli kanonizacji prawa państwowego, o których mówi kan.22 KPK (zob. Il diritto nel mistero della Chiesa, tom 1, Roma 1986, s.272-273). Szeroko na temat tych teorii można przeczytać w: M.E. O l m as Ortega, El matrimonio canónico en el Codigo civil de 1981, Revista Espagñola de Derecho Canónico 39, 1983, s. 52-57.

${ }^{2}$ Zob. R. Navarro Valls, dz.cyt., s. 120.

${ }^{3}$ „Lo Stato italiano, volendo ridonare all'istituto del matrimonio, che è base della famiglia, dignità conforme alle tradizioni cattoliche del suo popolo, riconosce al sacramento del matrimonio, disciplinato dal diritto canonico, gli effetti civili" (AAS 21, 1929, 17. 6, s. 290).

4 Prace nad rewizją konkordatu włoskiego rozpoczęły się od przedstawienia projektu rządowego (1969). Kolejne wersje przedkładano odpowiednio w 1976, 1977, 1978, 1979, 
proste stwierdzenie, które w kategoriach prawnych stara się opisać zasadę, na której opiera się mechanizm uznania skutków cywilnych małżeństwa kanonicznego. Brak bezpośrednich odniesień do sakramentalności małżeństwa nie zmienia przecież jego sakralnego wymiaru, ani też nie narusza jego istoty. Tekst konkordatu nie zajmuje się bowiem opisem małżeństwa $\mathrm{w}$ kategoriach religijnych, lecz prawnych, starając się skoordynować obie rzeczywistości w duchu autonomii i niezależności oraz zdrowego współdziałania, szanując prawa wiernych Kościoła i jednocześnie swoich obywateli.' Nie tyle więc należy mówić o cywilnym uznaniu małżeństwa kanonicznego, lecz raczej o uznaniu skutków cywilnych małżeństwa kanonicznego. ${ }^{2}$

Jeszcze wyraźniej można prześledzić ten proces na przykładzie rewizji konkordatu $\mathrm{z}$ Portugalią $\mathrm{z} 1940$ r. Tekst art.24 zawieral ogólne stwierdzenie, że katolicy, którzy zawarli małżeństwo w oparciu o przepisy tego konkordatu tym samym zrzekli się możliwości orzeczenia rozwodu cywilnego przewidzianego $w$ prawie portugalskim. ${ }^{3}$ Rewizja tego konkordatu przeprowadzona w 1975 r. utrzymała w mocy wszystkie jego przepisy, za wyjątkiem cytowanego wyżej. Nowe brzmienie art.24 zawiera deklarację Stolicy Apostolskiej potwierdzająca zobowiązanie wiernych do respektowania istotnych przymiotów małżeństwa oraz zalecenie nie odwoływania się do możliwości cywilnych rozwodów przez osoby, które zawarły małżeństwo kanoniczne. ${ }^{4}$ Również ta zmiana jest konsekwencją zasady autonomii obu porządków prawnych każdego w swoim zakresie, gdyż z jednej strony formułuje się zakaz wynikający z prawa kanonicznego,

1980, 1982 (dwie) i 1983 r. Wszystkie one zawieraly sformułowanie, które znalazło się w wersji podpisanej, z tym że w 1979 r. słowo „celebrati” zastapiono zwrotem „contratti”. Zob. Un Accordo di libertà La revisione del Concordato con la Santa Sede. La riforma della legislazione sugli enti ecclesiastici e i muovi rapporti con le altre confessioni religiose, Roma 1986, s. 456-457.

' Zob. A. V it a l e, Ordinamento giuridico e interessi religiosi. Corso di diritto ecclesiastico, Milano 1984, s. 218-219.

${ }^{2}$ M.in. P. M o n e t a (Matrimonio religioso e ordinamento civile, Torino 1991) rozdział poświęcony tej kwestii zatytułował il riconoscimento civile del matrimonio canonico (s. 21).

${ }^{3}$ "In armonia con le proprietà essenziali del matrimonio cattolico, si intende che per il fatto stesso della celebrazione del matrimonio canonico, i coniugi rinunzieranno alla facoltà civile di chiedere il divorzio, che perciò non potrà essere applicato dai tribunali civili ai matrimoni cattolici" (AAS 32, 1940, n. 7, s. 229-230).

${ }^{4}$ Zob. art. 1 protokołu, o którym mowa w przypisie 3 na s. 172. 
a $\mathrm{z}$ drugiej strony mówi się o istnieniu w prawie państwowym możliwości rozwodu, czyli cofnięcia cywilnych skutków związku w świetle przepisów tego prawa.'

$\mathrm{Z}$ punktu widzenia soborowej nauki o relacjach państwo-kościół opierających się na zasadzie niezależności i autonomii obu porządków w swoim zakresie, sformulowanie istniejące w konkordacie z $1940 \mathrm{r}$. mogło był rozumiane jako nieuzasadniona interferencja prawa kanonicznego w system prawa państwowego. Widoczna różnica formuł tradycyjnych i tych użytych w konkordatach posoborowych nie daje podstaw do utrzymywania twierdzenia o recepcji materialnej prawa kanonicznego do systemu prawa państwowego $\mathrm{w}$ zakresie regulacji małżeńskich. Soborowa zasada autonomii i niezależności znajduje także $w$ tym zakresie swoje praktyczne zastosowanie.

\section{a) państwo jako podmiot uznania skutków cywilnych małżeństwa kanonicznego}

Określenie podmiotu zobowiązania, a więc państwa, wydaje się być oczywistą konsekwencja płynąca z natury umowy konkordatowej: skoro zobowiązanie dotyczy skutków cywilnych wynikających $\mathrm{z}$ prawa państwowego, to ich uznanie względem małżeństwa kanonicznego należy do państwowej strony umowy konkordatowej. Użycie jednak z we włoskim i polskim konkordacie bezosobowego zwrotu (uznaje się, wywiera), bez imiennego odniesienia się do państwa (państwo uznaje), zdaje się zmieniać nieco prawną optykę tego - skądinąd - zupełnie logicznego wniosku. Niewaţpliwie $z$ formalnego punktu widzenia także we włoskim i polskim konkordacie państwo jest kompetentnym podmiotem, który może uznać skutki cywilne małżeństwa kanonicznego. Z drugiej jednak strony użycie określenia odbiegającego od formuły tradycyjnie stosowanej we wcześniejszych umowach konkordatowych nie może być traktowane jedynie w kategoriach językowych, lecz raczej winno być odczytywane w aksjologicznym odniesieniu do podstawowych praw wolnościowych, które przysługują człowiekowi w zakresie wolności religii oraz równości wobec prawa. $Z$ jednej strony nie jest koncesja państwa prawne uznanie woli jednostki, która wybiera religijną formę zawarcia małżeństwa², a z drugiej

'Zob. J.G.M. Carvaja1, dz. cyt., s. 253-254; R. M in ne rath, dz. cyt., s. 367.

2 Zob. M. Mart in e z C a vero, En torno al matrimonio civil de los católicos, Revista 
strony Kościół nie stawia oporu, aby małżeństwo zawarte $w$ formie religijnej mogło również osiagnąć te wszystkie skutki, jakimi cieszą się w ramach danego systemu prawa państwowego zwiazki małżeńskie wszystkich jego obywateli.'

\section{b) skutki cywilne małżeństwa konkordatowego}

Analiza terminu ,skutki cywilne" pojawiającego się w formułach konkordatowych nie jest zbyt często przedmiotem rozważań autorów. Wydawać by się mogło, że traktowany jest on przez wielu jako pojęcie pierwotne, oczywiste $i$ nie wymagające bliższego określenia. Dla pełni obrazu ewolucji zapisów konkordatowych w sprawach małżeńskich konieczne jest jednak poświęcenie kilku słów tej kwestii.

Jak już zostało to wspomniane na wstępie, doktryna katolicka mówiąc o małżeństwie chrześcijańskim uznaje kompetencję państwa w zakresie czysto cywilnych skutków małżeństwa. Pojęcie effectus mere civiles oznacza skutki doczesne małżeństwa, które nie są w sposób konieczny związane $\mathrm{z}$ istotą małżeństwa chrześcijańskiego. Stąd tė̇ niekiedy określane sa one jako effectus temporales separabiles. Tradycyjnie zalicza się do nich regulacje dotyczące wspólnoty majątkowej małżonków, dziedziczenia, nazwiska, tytułów, sprawy alimentacyjne. ${ }^{2}$ Uznana kompetencja państwa w tej dziedzinie nie rozciąga się już jednak - zgodnie z doktryną katolicką - na skutki cywilne, które w sposób konieczny związane są z małżeństwem, jak prawość pochodzenia, wzajemne prawa i obowiązki małżonków oraz rodziców i dzieci. ${ }^{3}$ Stąd też w starszych konkordatach można było spotkał klauzulę, zgodnie z którą państwo mogło

Española de Teologia 53, 1993, s. 105. Dość powszechna jest opinia, ze system fakultatywny najlepici odpowiada prawu do wolności religijnej (zob. tamże, s. 106, przypis 65).

' Chociaż stosunek Kościoła do instytucji małżeństwa cywilnego, przynajmniej na początku, trudnı nazwać „entuzjastycznym”, to jednak nie można twierdzić, że Kościół ignoruje znacrenie tego faktu spolecznego. Dowodem jest nie tylko wyraźne uznanie kompeteneji paisıwa w zakresie skutków czysto cywilnych (zob. kan.1059;1672;1692 §3) i praktyka zawierania konkordatów, ale również przywiązywanie do faktu zawarcia małżeństwa cywilnego wymiernych skutków na forum prawa kanonicznego (zob. kan.194 $§ 1,3^{3} ; 1041,3^{0}$; kan. $1394 \$ 1$ i 2).

lob. F.M. C a p pel1 o, dz. cyt., s. 66.

T a mże, s. 67. 
rozpatrywać sprawy o separację małżonków nie jako funkcję własną, lecz jako zadanie zlecone przez Kościól.'

Zgodnie z tym, co o interpretacji umowy konkordatowej powiedziano wcześniej, pojęcie „skutki cywilne” występujące w omawianych formułach konkordatowych oznacza więc wszystkie te skutki, które pociąga za sobą zawarcie małżeństwa w systemie prawnym danego państwa. Takie właśnie opisowe określenie skutków cywilnych można znaleźć w art.10 ust.1 konkordatu polskiego. Oznacza to w konsekwencji tylko tyle, że małżeństwo powstałe w oparciu o przepisy prawa kanonicznego, stwarzając między małżonkami węzeł ze swej natury nierozerwalny, może wywołać również te skutki, które przewidziane są w systemie prawa państwowego. ${ }^{2}$ A jeśli z jakiś powodów skutki cywilne zostałyby cofnięte przez rozwód, w niczym nie narusza to istnienia węzła małżeńskiego, którego ważność może był oceniana jedynie przez kompetentne instytucje kościelne.

\section{c) malzeństwo kanoniczne}

Pozostaje jeszcze do omówienia problem przedmiotu zobowiązania konkordatowego, a więc określenie małżeństwa, które na podstawie przepisów konkordatowych może być uznane za skuteczne w systemie prawa państwowego. W tekstach konkordatów posoborowych pojawiają się sformułowania opisowe, mówiące o małżeństwie zawartym zgodnie $\mathrm{z}$ prawem kanonicznym. ${ }^{3}$ Drobne zróżnicowania poszczególnych wyrażeń nie wydają się mieć większego znaczenia prawnego. Jedynie w konkordacie polskim zamiast określenia opisowego pojawia się termin „małżeństwo kanoniczne" na określenie małżeństwa, które zdolne jest wywołać skutki cywilne. W związku z tym może powstać pytanie o treść tego pojęcia. ${ }^{4}$

\footnotetext{
'Art. 34 (ostatnie zdanie) konkordatu włoskiego z 1929 r. stanowil, że "Stolica Apostolska zgadza się na to aby sprawy o separacje od stolu i loża rozpatrywane byly przez sady cywilne" (AAS 21, 1929, n. 6, s. 291). Podobny zapis można znaleźć w ust.2 protokołu dodatkowego do art. 7 konkordatu austriackiego z 1933 r. (AAS 26, 1934, n. 7, s. 277). Wprawdzie formalnie podobny zapis znajduje się jeszcze w konkordacie kolumbijskim z 1973 r. (art. 9), lecz z wyraźnym powołaniem się na uzgodnienie stron (le Alte Parti Contraenti convengono...), a nie $z$ udzielenia jednej ze stron (la Santa Sede consente...).

2 Zob.M.E.O 1 m os Orteg a, dz. cyt., s. 58.

${ }^{3}$ Zob. R. M in ne rat h, dz. cyt., s. 354.

+ Właściwie pojawia się ono tylko w kontekście polskiego konkordatu (zob. obszeme
} 
Prawdą jest, że pojęcie małżeństwa kanonicznego nie pojawia się $w$ kodeksie prawa kanonicznego.' Na gruncie prawa kanonicznego nie ma w zasadzie potrzeby wprowadzania tego pojęcia, skoro całe kanoniczne prawo małżeńskie ex definitione mówi o małżeństwie kanonicznym. Różne kategorie małżeństwa, definiowane bliżej w kodeksie (np. małżeństwo ważne, małżeństwo ważne $\mathrm{i}$ dopełnione itd.) precyzują szerszą kategorię, jaką jest właśnie małżeństwo kanoniczne, czyli kościelne, a więc zawarte stosownie do przepisów prawa kanonicznego. ${ }^{2}$ Jest jednak również prawda, że w obrębie prawa konkordatowego, a więc już nie tylko kościelnego prawa własnego, pojęcie to jest obecne. W tekstach omawianych konkordatów pojawia się ono wielokrotnie ${ }^{3}$, w taki mianowicie sposób, że najpierw podane jest określenie opisowe, a następnie używa się zwrotu technicznego "małżeństwo kanoniczne". Fakt ten dodatkowo potwierdza interpretację, że małżeństwo kanoniczne to nic innego, jak małżeństwo zawarte zgodnie $\mathrm{z}$ przepisami prawa kanonicznego. ${ }^{4}$ Bardziej złożone $\mathrm{i}$ odnoszące się do sfery doktrynalnej regulowanej w prawie kanonicznym formuły używane w starszych konkordatach (np. w konkordacie włoskim z 1929 r.) wprowadzały pewne ograniczenia w zakresie uznawania skutków cywilnych małżeństwa kanonicznego. W świetle przepisów konkordatu włoskiego z 1929 r. możliwość uznawania skutków cywilnych małżeństwa kanonicznego zawartego według formy nadzwyczajnej, a więc w obecności dwóch świadków zwykłych, była kwestionowana. ${ }^{5}$ Współczesne formuły uproszczone i wolne od treści doktrynalnych - spowodowaly powrót tego tematu. Od strony teoretycznej określenie „zgodnie $\mathrm{z}$ prawem

rozważania na temat tej kwestii w: P. K u g l a r z, F. Z o ll, Matżeństwo konkordatowe, Kraków 1994, s. 47-54).

' Zob. P. Kuglarz, F. Zoll, dz. cyt., s. 48.

${ }^{2}$ W. G ó r a $1 \mathrm{~s} \mathrm{k} \mathrm{i,} \mathrm{W.} \mathrm{A} \mathrm{d} \mathrm{a} \mathrm{m} \mathrm{c} \mathrm{z} \mathrm{e} \mathrm{w} \mathrm{s} \mathrm{k} \mathrm{i,} \mathrm{Konkordat} \mathrm{między} \mathrm{Stolicq} \mathrm{Apostolskq} i$ Rzeczapospolitq Polskq z 28 lipca 1993 r., Plock 1994 r., s. 55.

Zob. Kolumbia (art. 8; ust. I i 2 protokołu końcowego do art. 7; protokół końcowy do art. 9). Portugalia (art. 1). Hiszpania (art. 6 ust. 1 i 3; protokół końcowy do art. 6 ust. 1).

"Użycie określenia „małżeństwo sakramentalne” nie byłoby precyzyjne. Małżeństwo katolika z osobą nie ochrzczoną przy dyspensie od przeszkody jest prawdziwym małżeństwem kanonicznym, ale co do jego sakramentalności istnialy zdania rozbieżne (zob. F.M. Cappello, dz. cyt., s. 31-32). Obecnie przyjmuje się powszechnie, że nie jest ono sakramentalne (zob. J.M. Castaño, De quibusdam difficultatibus contra formulam can. 1012 $\S 2$, scilicet 'quin sit eo ipso sacramentum', Periodica 67, 1978, s. 269, przyp. 1).

${ }^{5}$ Zob. C. C a rdi a, Stato e confessioni religiose. Il regime pattizio, Bologna 1988, s. 331. 
kanonicznym" da się pogodzić z teza, że także małżeństwo zawarte w formie nadzwyczajnej może wywołać skutki cywilne.'

\section{Mechanizm uznawania skutków cywilnych małżeństwa kanonicznego}

Poprzednia część rozważań dotyczyła ogólnej zasady umocowania prawnego instytucji małżeństwa konkordatowego. Trzeba jednak pamiętać, ze mechanizm uznawania skutków cywilnych opisany jest przez wiele warunków, z których podstawowym jest konieczność „wpisu" (transcrizione), czyli zapisania zawartego małżeństwa kanonicznego w rejestrach państwowych. ${ }^{2}$ Chociaż jednak wszystkie konkordaty posoborowe przewidują konieczność wpisu w rejestrach państwowych, szczególowa procedura transkrypcji różni się w zależności od konkretnego konkordatu. Stąd też wydaje się usprawiedliwione - w przeciwieństwie do opisu zasad ogólnych - potraktowanie tej czesści bardziej indywidualnie i osobne omówienie poszczególnych konkordatów.

\section{a) konkordat kolumbijski (1973)}

Skuteczność prawna zasady uznawania skutków cywilnych malżeństwa kanonicznego uzależniona jest od przesłania przez kompetentną władzę kościelną ${ }^{3}$ autentycznej kopii aktu zawartego małżeństwa do

'Tak np. utrzymuje L. De L u c a (// riconoscimento del matrimonio canonico, Diritto Ecclesiastico 95, 1984, n. 1, 420-422). Argumentacja autora jest dość przekonująca w sensie teoretycznym, ale trudna do utrzymania $w$ świetle przepisów włoskich wprowadzających konkordat $\mathrm{w}$ życie.

${ }^{2}$ Po raz pierwszy procedure wpisu do rejestrów państwowych zastosowano $\mathrm{w}$ konkordacie $\mathrm{z}$ Kolumbią z 1887 r, co jednak nie przeszkadzało, aby jeszcze w konkordacie litewskim z 1927 r. uznawano skutki cywilne małżeństwa kanonicznego bez konieczności dokonywania transkıypcji, co w konsekwencji wiązało się z uznaniem skuteczności na forum prawa państwowego kościelnych rejestrów parafialnych. Zob. $R$. M i n n e $\mathrm{r}$ a $\mathrm{t} h$, dz. cyt., s. 347-348.

${ }^{3}$ Kopię dokumentu wysyła prọboszcz miejsca zawarcia małżeństwa. Zob. Conferencia Episcopal de Colombia, Normas complementarios del Código de Derecho Canónico z dnia 17-20 lutego 1986 r. Decreto n. 24 sobre inscricion de matrimonios (art.3), w: Ius Ecclesiae 3, 1991, n. 1, s. 398 . 
kompetentnego urzędnika państwowego, który z kolei zobowiązany jest do przepisania go do państwowych rejestrów malżeńskich.

W stosunku do uprzednio istniejącego porządku prawnego $w$ tej dziedzinie, postanowienia konkordatu z 1973 r. wprowadzily pewne uproszczenia, chociaż zasadniczy warunek - wpis do rejestru państwowego - pozostał $w$ swej istocie nie naruszony. Zrezygnowano jednak $z$ wymogu obecności w czasie zawierania małżeństwa kanonicznego urzędnika państwowego, który to warunek jako bezwzględny wpisany był w art.17 konkordatu z 1887 r.' Wokół zapisów konkordatu z 1887 r. już w 1923 r. powstały liczne kontrowersje, gdy postawiono formalne pytanie czy przepis ten należy stosować również do tych katolików, którzy formalnym aktem opuścili Kościół katolicki. Trzeba bowiem pamiętać, że dla osób należących do Kościoła katolickiego zawarcie małżeństwa w formie kanonicznej było jedynym sposobem uzyskania skutków cywilnych. ${ }^{2}$ Ostatecznie sprawę tę rozwiazano kompromisowo przez wydanie w 1924 r. ustawy państwowej, konsultowanej z racji związków z interpretacją konkordatu ze Stolica Apostolska. ${ }^{3}$ Rozwiązanie to okazało się jednak niewystarczające. Pierwsze próby przeprowadzenia reformy konkordatowych zapisów małżeńskich podjęto $\mathrm{w} 1942 \mathrm{r}$., ale proces ten nie został dokończony. ${ }^{+}$

Kolejna fala krytyki małżeńskich zapisów konkordatu z $1887 \mathrm{r}$. nastapiła w związku z recepcja nauki soboru watykańskiego II. Zarówno art. 17 konkordatu, jak przede wszystkim ustawa z 1924 r. była - zdaniem krytyków - niezgodna z soborową zasadą wolności religijnej. Równie krytycznie oceniano przepisany konkordatem obowiązek uczestniczenia urzędnika państwowego przy zawieraniu małżeństwa w formie kanonicznej. ${ }^{5}$

Zob. A. Mercat i, dz. cyt., tom 1, s. 1056.

2Zob. J. Prader, dz. cyt., s. 153.

${ }^{3}$ Ostatecznie ustalono, że przepisu tego nie stosuje się do apostatów, dając im - pod pewnymi warunkami - możliwość zawarcia bezpośrednio malżeństwa cywilnego. Uregulowania te nie miały jednak zastosowania do apostatów-kapłanów lub zakonników o ślubach wieczystych. Zob. A. T a b o $\mathrm{n}$ M e j i a, La situacion concordataria colombiana, w: La institución concordataria en la actualidad, Salamanca 1971, s.315-316. Wymiana oficjalnych not dyplomatycznych w tej sprawie: zob. A. M e r c at i, dz. cyt., tom. 2, s. 10-16.

+ Tekst projektu można znaleźć w: A. T a b o n M e j i a, dz. cyt., s. 295-297, a blizsze informacje na temat losów przygotowanej umowy: t a m z e, s. 316-317.

"Zob. t a m ż e, s. 322-323. Warto dodać, że w przygotowywanej reformie konkordatowej w 1942 r. odstapiono od bezwzględnej konieczności uczestniczenia urzędnika państwowego w celebracji małzeństwa kanonicznego. 
Postulaty te rzeczywiście znalazły swój pozytywny wyraz w nowym konkordacie z 1973 r., dostosowując go do nowej sytuacji politycznej i eklezjalnej.' Oprócz rezygnacji $\mathrm{z}$ obecności urzędnika państwowego, opuszczono także klauzulę wyłączności, która w poprzednich unormowaniach przewidywała, że jedynym sposobem osiagnięcia skutków cywilnych dla osób wyznajacych wiare katolickq było zawarcie małżeństwa w formie przepisanej przez sobór trydencki $i^{2}$. Ważnym dopowiedzeniem jest również ustalenie explicite zasady, że dokonanie wpisu do rejestrów państwowych powoduje uznanie skutków cywilnych małżeństwa od chwili jego zawarcia w formie kanonicznej (ust.2 protokołu końcowego do art.7). $\mathrm{Z}$ punktu widzenia dobra osób zawierających małżeństwo istotny jest także zapis ust.1 protokolu końcowego do art.7, który postanawia, że jeśli warunek przesłania uwierzytelnionego świadectwa zawarcia małżeństwa kanonicznego nie został dopełniony zaraz po jego celebracji, można go uzupełnić w każdym czasie, nawet po śmierci jednego lub obojga małżonków. Z wnioskiem takim może wystapić któryś z małżonków lub osoba trzecia majaca w tym interes prawny (np. dzieci).

\section{b) konkordat portugalski (1975)}

Przepisy dotyczace uznania skutków cywilnych małżeństwa zawartego zgodnie $\mathrm{z}$ prawem kanonicznym znajdują się $\mathrm{w}$ art.22 i 23 przepisów konkordatu z $1940 \mathrm{r}$. utrzymanych w mocy przez art.2 protokołu z $1975 \mathrm{r}$. Przewidują one - zgodnie $\mathrm{z}$ powszechną praktyką konkordatów posoborowych - instytucję wpisu faktu zawarcia malżeństwa kanonicznego w rejestrach państwowych. Jednocześnie precyzuje się, że obowiązek przesłania uwierzytelnionej kopii aktu zawarcia małżeństwa kanonicznego

\footnotetext{
' Nowa fala dyskusji wokół konkordatu kolumbijskiego miała ostatnio miejsce w związku z rozpatıywaniem przez Trybunał Konstytucyjny skargi związanej z konkordatem. Ponieważ jednak sprawa dotyczyła rozwodów, a więc nie uznawania, lecz rozwiązywania skutków cywilnych małżenstwa kanonicznego, nie wydaje się konieczne wchodzenie w szczególy problemu $w$ niniejszym opracowaniu.

2 Trzeba pamiętać, że w chwili podpisywania konkordatu z 1887 r. nie było jeszcze kodeksu prawa kanonicznego. Odwołanie się więc bezpośrednio do soboru trydenckiego spowodowane było racjami redakcyjnymi. Można więc traktować je porównywalnie ze współczesnymi klauzulami: „zgodnie z przepisami prawa kanonicznego".
} 
do urzędu stanu cywilnego celem dokonania wpisu spoczywa na proboszczu. Konkordat nie precyzuje bliżej o jakiego proboszcza chodzi.'

Przepisy konkordatu portugalskiego, w stosunku do prostych mechanizmów zawartych w konkordacie kolumbijskim, są znacznie bardziej rozbudowane. Na szczególną uwage zasługują dwie kwestie, a mianowicie wprowadzenie instytucji zapowiedzi w urzędzie stanu cywilnego oraz określenie terminów, w których należy dokonać czynności związanych z wpisem małżeństwa kanonicznego.

Obok zapowiedzi małżeńskich przewidzianych prawem kanonicznym, konkordat przewiduje zgłoszenie zamiaru zawarcia małżeństwa konkordatowego we właściwym urzędzie stanu cywilnego. Ponieważ mają one na celu - podobnie jak w przypadku zapowiedzi kanonicznych upewnienie się, że nic nie stoi na przeszkodzie do zawarcia małżeństwa w świetle przepisów prawa państwowego, ${ }^{2}$ procedura ta kończy się wydaniem przez urzędnika stanu cywilnego odpowiedniego zaświadczenia. ${ }^{3}$ Obowiązek zapowiedzi nie jest jednak bezwzględny. Podobnie jak w przypadku zapowiedzi kanonicznych możliwa jest dyspensa, tak $w$ przypadku zapowiedzi cywilnych przepisy konkordatu określaja sytuacje, które zwalniają z tego obowiązu. I tak, in articulo mortis, w sytuacji bliskiego porodu lub gdy do natychmiastowego zawarcia małżenstwa strony zostaną $-\mathrm{z}$ poważnych powodów natury moralnej - wyraźnie upoważnione przez własnego ordynariusza, można dopuścić do zawarcia małżeństwa kanonicznego bez uprzedniego przeprowadzenia procedury zapowiedzi $w$ urzędzie stanu cywilnego. Małżeństwo takie będzie mogło był później wpisane do rejestru państwowego, o ile nie okaże się, że któraś ze stron pozostaje $w$ nierozwiązanym związku cywilnym z osobą trzecią. ${ }^{4}$

Zapisy konkordatowe precyzują też terminy, w jakich należy dokonać czynności prawnych mających na celu uznanie skutków cywilnych małżeństwa kanonicznego. Można wymienił trzy takie czynności, to znaczy

' Przyjmuje się, że chodzi o proboszcza miejsca zawarcia małżeństwa (zob. J. P r a d e r, dz. cyt., s. 482).

${ }^{2}$ Warto pamiętać, że granica wieku pozwalającego na zawarcie małżeństwa w Portugalii to ukończony 16 rok życia, z tym że $w$ przypadku małoletnich (do ukończenia 18 roku życia) wymaga się zgody rodziców (opiekunów prawnych) lub upoważnienia sądowego. Zob. J. Pra d e r, dz. cyt., s. 480 .

${ }^{3}$ Zob. A. L e it e, El matrimonio civil y el divorcio en Portugal, w: El hecho religioso en la nueva Constitución española, Salamanca 1979, s.257.

* T a m że. 
przesłanie uwierzytelnionej kopii aktu zawarcia małżeństwa, dokonanie wpisu w rejestrach stanu cywilnego oraz powiadomienie władzy kościelnej o dokonanej transkrypcji. Konkordat portugalski określa te terminy odpowiednio: proboszcz powinien przesłać kopię aktu zawarcia malżeństwa w ciągu trzech dni od jego zawarcia, urzędnik stanu cywilnego ma dwa dni na dokonanie wpisu, a najpóźniej w dniu następnym $-z$ podaniem daty wpisu - powinien poinformowal o tym właściwego proboszcza. Należy dodać, że zaniedbanie tych terminów bez odpowiednio ważnych racji stwarza podstawę do wymierzenia sankcji tak w stosunku do proboszcza, jak i urzędnika państwowego.

Niezależnie od terminów określonych na dokonanie czynności prawnych, o których była mowa, konkordat portugalski ustala ostateczną zasadę, że tylko te małżeństwa kanoniczne będą mogły osiagnąc skutki cywilne od chwili ich zawarcia, których wpis w aktach stanu cywilnego został dokonany w nieprzekraczalnym terminie siedmiu dni. W pozostałych przypadkach, także po śmierci jednego lub obydwojga małżonków, dokonanie wpisu małżeństwa powoduje powstanie skutków cywilnych, ale już tylko od dnia dokonania tego wpisu, a nie od dnia zawarcia małżeństwa kanonicznego.

Trzeba przyznać, że konkordat z 1940 r., podpisany w oparciu o konstytucje portugalską z 1933 r., uchodził - w gruncie rzeczy - za zgodny z zasadami wolności religijnej.' $\mathrm{Z}$ drugiej jednak strony poważne wątpliwości były stawiane wobec zapisu art.24, który zawierał zakaz rozpatrywania przez sądy państwowe spraw rozwodowych osób, które zawarły małżeństwo w formie konkordatowej. Wśród licznych argumentów przeciwnych zachowaniu tego zakazu konkordatowego ${ }^{2}$ podkreślano, że nie jest on do pogodzenia $\mathrm{z}$ soborową nauką o autonomii i niezależności państwa i kościoła, a egzekwowanie przez instytucje państwowe konsekwencji małżeństwa sakramentalnego (lub szerzej - kanonicznego) nie należy do obowiązków państwa. Ostatecznie protokół dodatkowy $z$ 1975 r. zmienił kontrowersyjny przepis art.24 konkordatu z $1940 r^{3}$

\footnotetext{
'Zob. J.A. Fernandez Arruty, Portugal, w: C. Corral Sa I vador, Concordatos vigentes, tom 2, Madrid 1981, s.319-320; J. M i r a n d a, Libertà religiosa, Chiese e Stato in Portogallo, Quaderni di diritto e politica ecclesiastica 5, 1988, s. 212-213, 217.

${ }^{2}$ Szerzej na ten temat w: A. L e it e, dz. cyt., s. 260-261.

Szerzej była już o tym mowa wcześniej. Obecnie zadna umowa konkordatowa nie odnosi sie wprost do kwestii rozwodów. Jednak prawie we wszystkich konkordatach Stolica Apostolska
} 


\section{c) konkordat hiszpański (1979)}

Podobnie jak w pozostałych konkordatach posoborowych, warunkiem koniecznym do uznania skutków cywilnych' małżeństwa kanonicznego jest dopełnienie procedury wpisu zawartego małżeństwa kanonicznego $\mathrm{w}$ rejestrach państwowych. Zgodnie $\mathrm{z}$ art.6 ust. 1 oraz protokołem końcowym do tego artykułu, wystarczającym dokumentem dla dokonania wpisu jest przedstawienie zaświadczenia kościelnego o istnieniu małżeństwa kanonicznego. Jeśli zaś chodzi o sposób przekazania dokumentu kościelnego do urzędu państwowego - odmiennie niż w pozostałych konkordatach - przewidziany jest podwójny tryb. Po pierwsze, obowiązek ten spoczywa na małżonkach, którym kapłan asystujący przy zawieraniu małżeństwa winien $w$ tym celu przekazać zaświadczenie o zawarciu małżeństwa wraz z wszystkimi informacjami koniecznymi do dokonania wpisu. Po drugie, konkordat nakłada na proboszcza miejsca, w którym zawarto małżeństwo obowiązek przesłania - w każdym wypadku - do właściwego urzędnika stanu cywilnego aktu zawartego małżeństwa celem dokonania wpisu, o ile nie dokonano tego $\mathrm{z}$ braku wniosku przedstawionego przez zainteresowanych małżonków. ${ }^{2} \mathrm{O}$ ile w przypadku małżonków nie określa się terminu w jakim należy przesłać akt zawarcia małżeństwa, o tyle proboszcz zobowiązany jest wypełnić ten obowiązek w ciągu pięciu dni.

Procedura uznawania skuteczności cywilnej małżeństwa kanonicznego opiera się wyłącznie na dokumencie kościelnym. Zrezygnowano więc $\mathrm{z}$ formy zapisanej w konkordacie z 1953 r., która przewidywała możliwość obecności urzędnika państwowego podczas zawierania małżeństwa kanonicznego. ${ }^{3}$

przypomina i potwierdza naukę o nierozerwalności małżeństwa (zob. Portugalia - art. 1 protokołu dodatkowego; Hiszpania - art. 6 ust. 3; Włochy - art. 8 ust. 3, Polska - art. 11).

' Formalnie rzecz biorąc małzeństwo cywilne w Hiszpanii zostało wprowadzone w $1870 \mathrm{r}$. Zob. L. Port e ro Sá n c he z, Matrimonio civil en España, Razón y Fe 188, 1973, n. 12, s. 371 .

"W doktrynie hiszpańskiej zwykło się tę formę nazywać „wpisem uzupełniającym".

${ }^{3}$ Zob. lit. A ust. 1 protokohu końcowego do art. 23 (AAS 45, 1953, n. 13, s. 652). Przepis ten inspirowany był zapisem konkordatu kolumbijskiego z $1887 \mathrm{r}$., lecz nie miał już charakteru obligatoryjnego i uzasadniany był zasadami hiszpańskiego kodeksu cywilnego. Dokładniejsza analizę można znaleźć w: R. N a v a r ro Valls, dz. cyt., s. 128-131. 
Szczególnego znaczenia nabiera ostatnia część protokołu końcowego do art.6 ust.1 konkordatu hiszpańskiego. Zapis ten pośrednio dotyka problemu małżeństwa kanonicznego, które nie zostało wpisane do rejestru państwowego, a więc w konsekwencji jego skutki nie są uznawane $w$ systemie państwowego prawa cywilnego. Poprzedni konkordat z $1953 \mathrm{r}$. wprost i szeroko podejmował ten temat.' Obecne przepisy $w$ tej materii zawierają jedynie ogólne stwierdzenie, że państwo - do czasu uzyskania skuteczności na forum cywilnym - powinno zadbać o ochronę praw nabytych $w$ dobrej wierze przez osoby trzecie. Jak się wydaje przepis ten ma swoje uzasadnienie $w$ fakcie, że małżeństwo kanoniczne nie wpisane jest jednak aktem prawnym potencjalnie zdolnym do wywołania skutków na forum prawa państwowego, jeśli tylko zostaną spełnione odpowiednie formalności. ${ }^{2}$

\section{d) konkordat włoski (1984)}

W konkordacie włoskim uderza szczegółowy charakter przepisów dotyczących sposobu osiagnięcia skuteczności cywilnej małżeństwa kanonicznego. Wyraźnie też umieszczone jest zastrzeżenie, że nie podlegają wpisowi małżeństwa kanoniczne, które nie mogłyby być zawarte w świetle prawa państwowego.

Podstawowym warunkiem uzyskania skutków cywilnych małżeństwa kanonicznego jest dopelnienie procedury wpisu w aktach stanu cywilnego. ${ }^{3}$

\footnotetext{
'W doktrynie prawa konkordatowego istnieje pojęcie „małżeństwa nie wpisanego" (matrimonio non trascritto) i „wpisu spóźnionego" (trascrizione tardiva). Pierwszy przypadek ma miejsce wówczas, gdy - obojętnie $z$ jakich racji - przewidziana przez prawo transkrypcja małżeństwa kanonicznego do akt stanu cywilnego, stanowiąca warunek jego skuteczności cywilnej, nie została dokonana. Druga sytuacja polega na tym, że wpis zostaje dokonany, ale z przekroczeniem wyznaczonych przez prawo terminów. Bliżej na temat małżeństwa nie wpisanego zob. G. Lo C a s t 1 o, Rilevanza giuridica del matrimonio canonico non trascritto nell'ordinamento dello Stato, w: Studi in onore di Pietro Agostino D'Avack, tom. 2, Milano 1976, s. 917-955.

${ }^{2}$ Zob. R. N a v a r r o V a $11 \mathrm{~s}$, dz. cyt., s. 138. Wydaje się, że obowiązek ochrony przez państwo praw nabytych $\mathrm{w}$ tym wypadku bardziej opiera się na naturalnych umocowaniach instytucji małżeństwa, które dia ochrzczonych jest wyniesione do godności sakramentu. W literaturze można spotkać się z określeniem effetti preliminari na określenie tych skutków cywilnych małżeństwa, które niesie z sobą jego zawarcie w formie kanonicznej, nawet jeśli nie nabrały one jeszcze rzeczywistej skuteczności w świetle prawa państwowego. Zob. L o C a s t r o, dz. cyt., s. 938-945.

${ }^{3}$ Zgodnie $\mathrm{z}$ zaleceniem partykularnego prawa kanonicznego we Włoszech, katolicy winni
} 
Podobnie jak $w$ konkordacie portugalskim, wymaga się uprzedniego przeprowadzenia zapowiedzi cywilnych, które kończą się wydaniem przez właściwego urzędnika zaświadczenia, że nic nie stoi na przeszkodzie ze strony prawa państwowego do zawarcia konkretnego małżeństwa.' $\mathrm{Na}$ mocy konkordatu proboszcz lub duchowny delegowany, który asystuje przy zawieraniu małżeństwa powinien zaraz po jego celebracji odczytać małżonkom odpowiednie fragmenty włoskiego kodeksu cywilnego dotyczace praw i obowiązków malżeńskich oraz sporządzić świadectwo zawartego małżeństwa $w$ dwóch oryginalnych egzemplarzach. Małżonkowie zaś moga umieścić na nich dodatkowe oświadczenia przewidziane w kodeksie cywilnym. ${ }^{2}$ Pisemny wniosek o dokonanie wpisu winien był przesłany przez proboszcza miejsca zawarcia małżeństwa. Wpisu zaś dokonuje właściwy urzędnik stanu cywilnego, o ile oczywiście zachodzą warunki prawne do jego dokonania, i powiadamia o tym właściwego proboszcza. Również konkordat włoski ustala terminy prawne na dokonanie tych czynności. I tak, proboszcz powinien przesłał wniosek w ciągu pięciu dni od zawarcia małżeństwa, a urzędnik stanu cywilnego ma kolejne 24 godziny na dokonanie wpisu. Nie określa się natomiast terminu, w jakim ma nastapić powiadomienie o dokonaniu wpisu. Nowością konkordatu włoskiego jest fakt, że tylko pierwszy z tych terminów ma charakter bezwzględny i jego przekroczenie powoduje niemożliwość dokonania wpisu. Niemożliwość ta jest jednakże usuwalna poprzez zastosowanie procedury „wpisu spóźnionego”. W tym jednak wypadku z wnioskiem muszą wystapić małżonkowie, albo oboje, albo jeden $z$ nich za wiedza i bez sprzeciwu drugiego małżonka. Warunkiem wpisu $w$ takim wypadku jest pozostawanie małżonków $\mathrm{w}$ stanie wolnym $\mathrm{z}$ punktu widzenia przepisów kodeksu cywilnego przez cały okres od zawarcia małżeństwa kanonicznego do złożenia wniosku. Nie może także naruszać praw słusznie nabytych przez osoby trzecie.

korzystać z moźliwości uzyskania skutków cywilnych swojego małźeństwa kanonicznego. Jedynie w wyjątkowych przypadkach ordynariusz miejsca może dać swoje nihil obstot na zawarcie małżeństwa, które nie może być uznane w świetle przepisów prawa państwowego (kan.1071, 2" KPK). Zob. Conferenza Episcopale Italiana, Decreto generale sul matrimonio canonico z dnia 5 listopada 1990 r., w: Ius Ecclesiae 3, 1991, n.2, s.782. Por. także A. V it a le, dz. cyt., s. 224-225.

' Zob. art.4 ust.1 projektu ustawy n.1831/1987, w: S. B e r l i n g ò, G. C a s u s c e 1 I i, Codice del diritto ecclesiastico, Milano 1993, s. 348.

${ }^{2}$ Zgodnie $\mathrm{z}$ kodeksem cywilnym deklaracje te moga dotyczyć wspólnoty dóbr i uznania dziecka naturalnego. Zob. L. C h i a p p et t a, dz. cyt., s. 303. 
W sposób wyraźny określono, że małżeństwo uzyskuje skutki cywilne od momentu zawarcia, nawet jeśli urzędnik państwowy z jakiejkolwiek przyczyny dokonał wpisu po upływie przewidzianego terminu. Przepis ten wydaje się mieć zastosowanie także w przypadku wpisu spóźnionego, o czym świadczyłaby użyta klauzula ,z jakiejkolwiek przyczyny".'

Określa się też taksatywnie wypadki, w których małżeństwo nie może został wpisane do akt stanu cywilnego. Ma to miejsce wówczas, gdy małżonkowie nie odpowiadają warunkom dotyczącym wymaganego przez prawo cywilne wieku do zawarcia małżeństwa ${ }^{2}$ lub gdy istnieje między nimi przeszkoda uznawana przez prawo włoskie za nieusuwalna. Protokół dodatkowy do art. 8 (lit.a) wymienia trzy takie przeszkody, a mianowicie gdy któryś z nupturientów został uznany za chorego umysłowo, jest związany małżeństwem cywilnym lub związany jest przeszkodą występku lub powinowactwa w linii prostej.

\section{e) konkordat polski (1993)}

W porównaniu do pozostałych konkordatów posoborowych polska umowa wnosi nowe elementy w tę dziedzinę regulacji prawnych. Zacząć jednak wypada od omówienia elementów, które obecne są w pozostałych konkordatach.

Podstawową czynnością umożliwiającą uznanie skutków cywilnych małżeństwa kanonicznego jest - jak w każdym konkordacie - dokonanie wpisu $\mathrm{w}$ aktach stanu cywilnego. W przeciwieństwie do innych konkordatów nie precyzuje się jednak kto powinien przedstawić odpowiedni wniosek i jaki dokument musi był do niego dołączony. Zgodnie $\mathrm{z}$ praktyką stosowana $w$ innych krajach uznających system małżeństwa konkordatowego można więc przewidzieć trzy możliwości, mianowicie wniosek może być przedstawiony przez proboszcza miejsca zawarcia małżeństwa, przez małżonków lub solidarnie przez proboszcza i małżonków. Zgodnie z ust. 6 artykułu 10 rozstrzygnięcie tej kwestii należy do prawodawcy polskiego. Podobnie jak w większości konkordatów

\footnotetext{
1 Zob. L. Chi a p pett a, dz. cyt., s. 305.

${ }^{2}$ Art. 84 kodeksu cywilnego wymaga do zawarcia małżeństwa ukończenia 18 roku życia. Sąd może jednak z poważnych racji zezwolił na zawarcie małżeństwa osobie, która ukończyła 17 rok życia. Zob. M. M a r g a n $\mathrm{t}$ e, Il matrimonio. Diritto canonico. Diritto concordatario. Pastorale, Casale Monferrato 1992, s. 100-101.
} 
ustalony został termin prawny na przedstawienie tego wniosku. W myśl ust. 1 pkt 3 artykułu 10 wynosi on pięć dni, z tym że - czego nie ma już w innych konkordatach - ulega on przedłużeniu $z$ powodu zaistnienia sił wyższych aż do czasu ich ustania.

W konkordacie polskim nie został poruszony wprost problem tzw. wpisu spóźnionego, to znaczy dokonanego $z$ przekroczeniem ustalonego terminu pięciu dni. Po części jest ten problem rozwiązany wprowadzeniem instytucji ,siły wyższej", która ma moc zawieszająca bieg czasu. W zakresie, w jakim ta formuła okaże się niewystarczająca, zawsze istnieje możliwość skorzystania $\mathrm{z}$ formy zawarcia małżeństwa cywilnego bezpośrednio przed urzędnikiem stanu cywilnego, przewidziana w polskim kodeksie rodzinnym i opiekuńczym.

W świetle zapisów konkordatu polskiego - które jednak nie mają sankcji samowykonalności, a więc domagają się przepisów wykonawczych - nie ulega wątpliwości, że skutki cywilne małżeństwo kanoniczne osiaga z chwila jego zawarcia, a nie dopiero od momentu dokonania jego wpisu w aktach stanu cywilnego. Transkrypcja do akt stanu cywilnego jest formalnością która skutki cywilne czyni możliwymi do egzekwowania na forum prawa państwowego. Dotyka to problemu czy wpis do akt stanu cywilnego ma charakter konstytutywny czy jedynie deklaratywny. Pytanie to jest zasadne, ale - jak sądzę - nie najważniejsze z punktu widzenia prawa konkordatowego.'

Możliwość dokonania wpisu jest jednak uwarunkowana spełnieniem dwóch innych warunków zawartych w polskim konkordacie. Pierwszym i podstawowym $z$ nich jest zgodne oświadczenie woli nupturientów, złożone przy zawieraniu małżeństwa, dotyczące wywarcia takich skutków, oraz drugi warunek - nie istnienie między nimi przeszkód wynikających z prawa polskiego. ${ }^{2} \mathrm{O}$ ile ten drugi warunek jest dobrze znany $w$ systemie małżeńskiego prawa konkordatowego, o tyle pierwszy z nich jest nowością

\footnotetext{
' Analizę tego zagadnienia $z$ punktu widzenia polskiego systemu prawa cywilnego można znaleźć w: P. K u g l a r z, F. Z o I 1, dz. cyt., s. 56-57, 58. W myśl przepisów prawa polskiego wpis ma charakter konstytutywny. Do tego zagadnienia przyjdzie jeszcze powrócić w zakończeniu.

2 Szeroką analizę przeszkód wynikających z przepisów polskiego kodeksu rodzinnego i opiekuńczego ( $w$ porównaniu z przeszkodami z prawa kanonicznego) można znaleźć w: J. Dudziak, Zharmonizowanie kanonicznego prawa matżeńskiego i polskiego prawa rodzinnego w Konkordacie, w: Rola $i$ znaczenie Konkordatu 1993 r., Kraków 1994, s. 102-109; P. Kugla r z, F. Zoll, dz. cyt., s. 24-40.
} 
polskiego konkordatu. Kwestia autonomiczności woli zawierających małżeństwo w stosunku do wywołania skutków cywilnych sankcjonowanych prawem państwowym jest wprawdzie przedmiotem rozważań autorów', to jednak $\mathrm{w}$ żadnym $\mathrm{z}$ konkordatów uszanowanie wolności religijnej $i$ osobistej woli zawierających małżeństwo nie przekroczyło granic utartych rozwiązań tak dalece, jak konkordat polski. Nowa jakość tego zapisu, może być odczytywana tylko w świetle pełnego rozumienia zasady autonomii i niezależności porządku doczesnego i duchowego $z$ wszystkimi tego konsekwencjami. ${ }^{2}$

W świetle przepisów konkordatu, zamiar zawarcia małżeństwa kanonicznego ze skutkami cywilnymi powinien był ujawniony odpowiednio wcześniej, gdyż zgodnie z ust.2 artykułu 10 zależy od tego zakres przygotowania do zawarcia małżeństwa. Trzeba mieć także na uwadze przepis, który stawia warunek nieistnienia między nupturientami przeszkód wynikajacych $\mathrm{z}$ prawa polskiego. Właściwym miejscem na formalną weryfikację tego warunku jest oczywiście - zgodnie z zasadą rozdzielenia kompetencji - urząd cywilny, a nie kościelny. ${ }^{3}$ Zapis mówiacy, że oświadczenie woli dotyczące wywarcia skutków cywilnych ma być złożone przy zawieraniu malżenstwa jest na tyle szeroki, iż pozostawia ustawodawcy polskiemu wystarczające pole do wydania szczegółowych norm wykonawczych, które zadowalająco skoordynują oba wymiary małżeństwa konkordatowego. ${ }^{4}$

' Zob. szerokie studium zagadnienia w: R. N a v a r' ro V a lls, dz. cyt., s. 140-143.

${ }^{2}$ Wprawdzie tematem opracowania nie jest kompetencja sądowa w sprawach małżeńskich, ale trzeba $w$ tym miejscu przypomnieć, że przepisy polskiego konkordatu rozdzielaja te kompetencje $w$ sposób całkowity i nie przewidują możliwości sankcjonowania wyroków kanonicznych $w$ zakresie prawa państwowego. Warto też pamiętać, że ust. 5 artykułu 10 przewiduje możliwość zawarcia w przyszłości dodatkowych umów dotyczących jedynie wzajemnego powiadamiania o orzeczeniach sądów kościelnych i państwowych. Powiadamianje takie mogłoby stuzyć do wykorzystania materiału dowodowego (np. ekspertyz biegłych), ale samo uznawanie wyroków w innym porządku (kościelnym lub państwowym) niż ten $w$ którym zostaly wydane jest wykluczone przez ust. 3 i 4 tego artykutu.

${ }^{3}$ Zob. W. G ó r a ls k i, Zawieranie malżeństwa w świetle Konkordatu, w: Prawda o Konkordacie, Częstochowa 1994, s. 114. Wydaje się to słuszne również w stosunku do przeprowadzania pouczenia o przepisach prawa polskiego dotyczących skutków małżeństwa (zob. art. 10 ust. 2), chociaż $w$ konkordacie włoskim ten wymóg jest spelniany poprzez odczytanie $w$ czasie zawierania małżeństwa kanonicznego odpowiednich fragmentów włoskiego kodeksu cywilnego.

${ }^{+}$T a m że, s. 116-117. 


\section{Małżeństwo konkordatowe - między niezależnością i współdziałaniem}

We wszystkich konkordatach posoborowych podstawowym warunkiem uzyskania przez małżeństwo kanoniczne skutków cywilnych w rozumieniu prawa państwowego jest dokonanie wpisu tego małżeństwa w aktach stanu cywilnego. Instytucja ta, która $z$ pewnym trudem znalazła swoje zupełnie dziś naturalne umocowanie prawne', jest przejawem usprawiedliwionej $\mathrm{i}$ zgodnej z doktryną Kościoła zasady autonomii ${ }^{2}$ porządku państwowego $\mathrm{i}$ duchowego, które zachowują kompetencje i niezależność - każde w swoim zakresie. $^{3}$

Z punktu widzenia dobra konkretnego czlowieka i całych społeczności, nie wystarcza jednak podkreślanie tej zasady, a nawet wprowadzenie jej w prawne ramy życia społecznego. W tej bowiem perspektywie organicznym uzupełnieniem niezależności i autonomii jest zasada zdrowego współdziałania wynikająca z prostego faktu, że członkowie Kościoła są również obywatelami państwa. W dziedzinie spraw stanowiących przedmiot słusznego zainteresowania obu podmiotów, rozumna wydaje się

' We współczesnej nauce wymienia się dwie racje usprawiedliwiające ten wymóg prawa konkordatowego. Pierwsza ma charakter bardziej polityczny, a mianowicie państwo egzekwuje swoje prawa wobec systemu prawnego obcego - a takim jest również prawo kanoniczne $w$ stosunku do prawa danego państwa. W gruncie rzeczy jest to pośrednie uznanie Kościoła jako odmiennego ale równoprawnego partnera względem państwa. Druga racja ma charakter techniczno-prawny i polega na dążeniu państwa do zapewnienia obywatelom jednorodnego systemu prawa małżeńskiego, a przez to samo pragnie dać większe gwarancje pewności w obrocie prawnym. Zob. R. M in nerath, dz. cyt., s. 351; R. N a var ro Valls, dz. cyt., s. 132; A. V i t a l e, dz. cyt., s. 218-219.

"Szukając różnicy znaczeniowej terminów „autonomia” i „niezależność", trzeba zauważył, że chociaż w gruncie rzeczy dotyczą tego samego atrybutu, to jednak ,niezależnośc” oddaje go w relacjach zewnętrznych (ad extra): kościół jest niezależny od państwa, państwo jest niezależne od kościola, podczas gdy ,autonomia" dotyczy relacji wewnętrznych (ad intra): kościół jest autonomiczny w zarządzaniu swoimi sprawami i stanowieniu norm religijnych itd.

${ }^{3}$ Pewne ciekawe intuicje tej zasady można znaleźć $w$ odpowiedzi rądu włoskiego na zarzut, że w ustawie $z$ dnia 27 maja 1929 r., która wprowadzała $w$ życie przepisy konkordatu laterańskiego, nie użyto terıninu „małżeństwo sakramentalne” znajdującego się w konkordacie. Podkreślano wówczas, że użycie tego terminu w konkordacie było zrozumiałe, ponieważ jest to akt dwustronny, natomiast $w$ ustawie państwowej wydawało się bardziej stosowne uniknąć komplikowania norm prawa cywilnego poprzez odwoływanie się do określonych koncepcji teologicznych. Zob. L. C h i a p p e $t \mathrm{t}$ a, dz. cyt., s. 302, przypis 32 . Nawiasem mówiąc, zapis ustawy włoskiej z 1929 r. mówiący o małżeństwie zawieranym wobec duchownego katolickiego nie do końca wiernie oddaje zapis konkordatowy. 
konieczność koordynacji obu wymiarów życia człowieka. Sam fakt zawierania konkordatów jest przejawem takiej koordynacji, a ogólne formuły o uznaniu skutków cywilnych małżeństw zawieranych w formie kanonicznej są praktycznym dowodem szanowania wolności religijnej obywateli. $Z$ tego punktu widzenia najważniejsze jest praktyczne skoordynowanie obu systemów prawnych, bez ich niepotrzebnej interferencji, tak aby to samo wydarzenie w życiu człowieka (małżeństwo) mogło być dla niego wypełnieniem zasad wyznawanej wiary, a jednocześnie mogło wywołać skutki na forum państwowego prawa cywilnego, w całości takie, jak i pozostałych obywateli państwa. W tym sensie dyskusja nad momentem konstytuującym małżeństwo powinna uwzględniać ten złożony wymiar regulacji konkordatowej. Ze strony zawierającego małżeństwo kanoniczne węzeł małżeński - ze swej natury wieczysty i wyłączny' - powstaje z chwilą jego zawarcia zgodnie z przepisami prawa kanonicznego. Dalsza procedura ma na celu nadanie skutków cywilnych tak powstałego związku. I staje się tak po dopełnieniu tej procedury w ogólnych ramach określonej w umowie konkordatowej, a w szczegółach unormowanej przepisami wykonawczymi ustanowionymi przez stronę państwową tej umowy.

Z punktu widzenia prawa do wolności religijnej, godne podkreślenia jest rozwiązanie zawarte w polskim konkordacie, które uzależnia możliwość uznania skutków cywilnych małżeństwa kanonicznego od złożenia zgodnego oświadczenia małżonków w tej sprawie. Mogą więc małżonkowie zawrzeć małżeństwo kanoniczne w formie konkordatowej, ale mogą też skorzystać sukcesywnie $z$ obu tych form - kanonicznej $i$ cywilnej - aby osiagnać ten sam status prawny. $W$ ich własnym interesie jest, aby związek religijny miał zapewnione skutki cywilne. Ale pozostawienie zasady, że zależy to od ich własnej decyzji, jest jednak bliższe ideałom praw wolnościowych przysługujących człowiekowi z racji jego ludzkiej godności.

' Zob. kan. 1134 KPK. 